Annales Geophysicae (2003) 21:2175-2183 (C) European Geosciences Union 2003

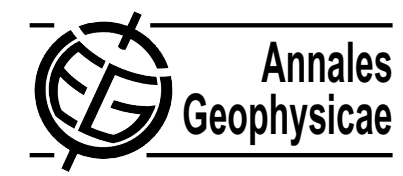

\title{
Antarctic air over New Zealand following vortex breakdown in 1998
}

\author{
J. Ajtic ${ }^{1,2}$, B. J. Connor ${ }^{2}$, C. E. Randall ${ }^{3}$, B. N. Lawrence ${ }^{4}$, G. E. Bodeker ${ }^{2}$, J. E. Rosenfield ${ }^{5}$, and D. N. Heuff ${ }^{1}$ \\ ${ }^{1}$ Department of Physics and Astronomy, University of Canterbury, Private Bag 4800, Christchurch 8020, New Zealand \\ ${ }^{2}$ National Institute of Water and Atmospheric Research, Private Bag 50061, Omakau 9182, Central Otago, New Zealand \\ ${ }^{3}$ Laboratory for Atmospheric and Space Physics, UCB 392, University of Colorado, Boulder, CO 80309-0392, USA \\ ${ }^{4}$ British Atmospheric Data Centre, Rutherford Appleton Laboratory, Chilton, Didcot, OX11 0QX, UK \\ ${ }^{5}$ Goddard Earth Sciences and Technology Center, NASA/Goddard Space Flight Center, Code 916, Greenbelt, MD 20771, \\ USA
}

Received: 6 May 2002 - Revised: 31 March 2003 - Accepted: 17 April 2003

\begin{abstract}
An ozonesonde profile over the Network for Detection of Stratospheric Change (NDSC) site at Lauder $\left(45.0^{\circ} \mathrm{S}, 169.7^{\circ} \mathrm{E}\right)$, New Zealand, for 24 December 1998 showed atypically low ozone centered around $24 \mathrm{~km}$ altitude ( $600 \mathrm{~K}$ potential temperature). The origin of the anomaly is explained using reverse domain filling (RDF) calculations combined with a $\mathrm{PV} / \mathrm{O}_{3}$ fitting technique applied to ozone measurements from the Polar Ozone and Aerosol Measurement (POAM) III instrument. The RDF calculations for two isentropic surfaces, 550 and $600 \mathrm{~K}$, show that ozone-poor air from the Antarctic polar vortex reached New Zealand on 2426 December 1998. The vortex air on the $550 \mathrm{~K}$ isentrope originated in the ozone hole region, unlike the air on $600 \mathrm{~K}$ where low ozone values were caused by dynamical effects. High-resolution ozone maps were generated, and their examination shows that a vortex remnant situated above New Zealand was the cause of the altered ozone profile on 24 December. The maps also illustrate mixing of the vortex filaments into southern midlatitudes, whereby the overall midlatitude ozone levels were decreased.
\end{abstract}

Key words. Atmospheric composition and structure (middle atmosphere composition and chemistry) - Meteorology and atmospheric dynamics (middle atmosphere dynamics)

\section{Introduction}

The dilution of ozone-poor air that takes place after breakdown of the polar vortices has an important effect on midlatitude ozone levels. Evidence for vortex filaments reaching midlatitudes in both hemispheres has been given in a number of studies (e.g. Bowman, 1993; Waugh et al., 1997). In northern midlatitudes, Knudsen et al. (1998) found that the dilution of chemically depleted ozone air from the Arctic vortex plays a significant role in spring and summertime ozone decline. Atkinson et al. (1989) showed that atypically low total ozone values over New Zealand and Australia, in Decem-

Correspondence to: J. Ajtić (j.ajtic@ niwa.co.nz) ber 1987, resulted from transport of ozone-poor Antarctic air into southern midlatitudes. In that event, a significant contribution of ozone hole dilution into midlatitudes was reported by Atkinson and Plumb (1997). Model results of Eckman et al. (1996) showed that after breakdown, ozone-depleted air from the Antarctic vortex reaches latitudes of $\sim 20^{\circ} \mathrm{S}$ and that, before the onset of the next ozone depletion cycle, the ozone levels do not reach the levels of the previous year. The severity of Antarctic ozone depletion has steadily increased over the past two decades (Bodeker et al., 2002). Furthermore, the negative ozone trends observed over the National Institute of Water and Atmospheric Research (NIWA) site in Lauder $\left(45.0^{\circ} \mathrm{S}, 169.7^{\circ} \mathrm{E}\right)$ are greater in summer than in any other season (WMO, 1999). Therefore, the dilution processes might be the most important cause of the ozone decreases over New Zealand in summer.

A case study of the influence of the Antarctic vortex breakdown on the ozone levels above New Zealand in 1998 is presented here. The cause of an anomalous vertical profile of ozone over Lauder is examined. In addition, a method for generating high-resolution ozone maps for an isentropic surface, used here to illustrate the evolution of the stratosphere after breakdown of the vortex, is introduced.

\section{Analysis and results}

Ozonesonde profiles have been measured at the NIWA site in Lauder from August 1986 to the present (Bodeker et al., 1998). The profiles for 14 and 24 December 1998 are shown in Fig. 1.

The two profiles differ considerably. While the profile for 14 December resembles a typical midlatitude December ozone profile, ozone on 24 December was less abundant in the whole region between the potential temperature surfaces of 350 and $750 \mathrm{~K}$, with two conspicuous reductions, between 550 and $650 \mathrm{~K}$, and 680 and $740 \mathrm{~K}$.

Total column ozone dropped from $311 \mathrm{DU}$ on 14 December to $253 \mathrm{DU}$ on 24 December. This difference was 

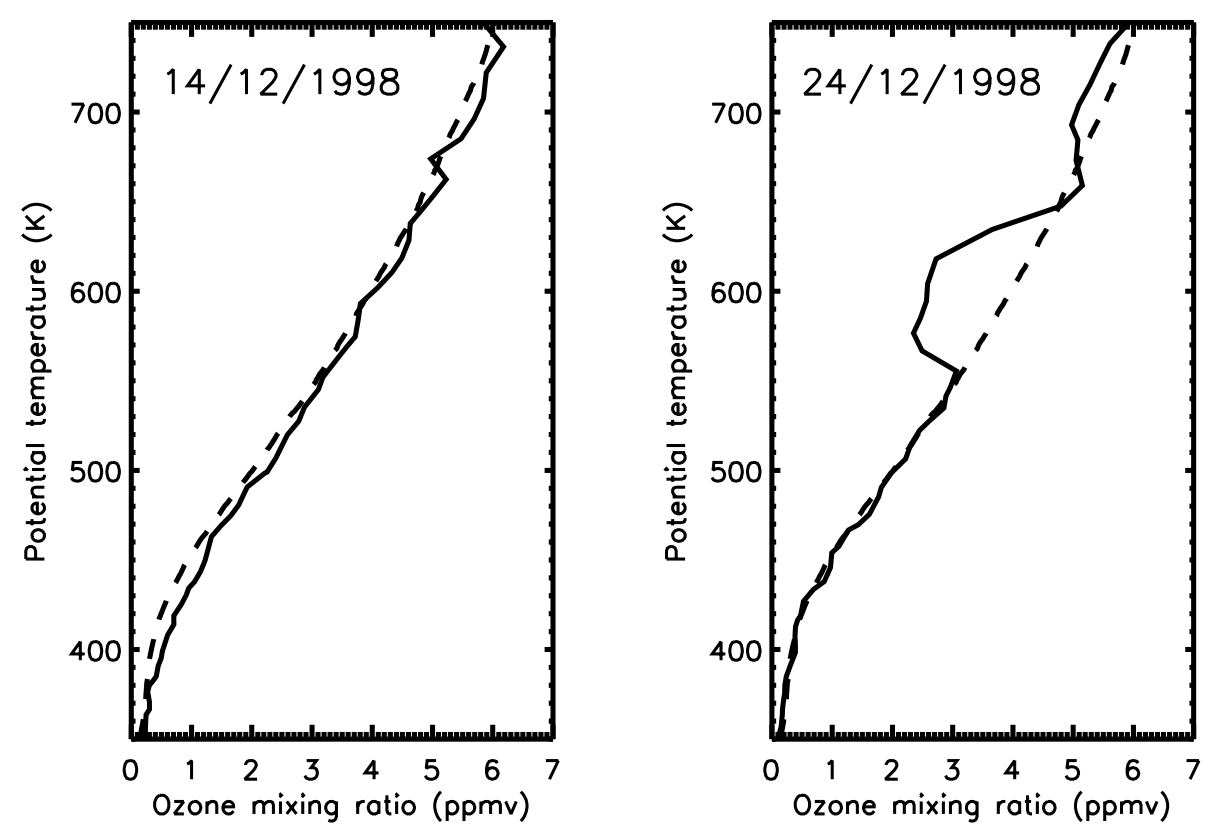

Fig. 1. Vertical profiles of ozone (between potential temperature surfaces of 350 and $750 \mathrm{~K}$ ) for 14 and 24 December 1998 , over Lauder, New Zealand (full line). The ozonesonde climatology for the month of December (1986-2001) is plotted for comparison (dashed line).

caused solely by the changes in the ozone profile between 350 and $750 \mathrm{~K}$. The layer between 550 and $650 \mathrm{~K}$ contributed $\sim 32 \mathrm{DU}$ to the decrease. The reduction in the ozone mixing ratio between the 350 and $450 \mathrm{~K}$ isentropes, contributed another $\sim 22 \mathrm{DU}$, and the reduction in the $100 \mathrm{~K}$-layers centred around 500 and $700 \mathrm{~K}$ added $\sim 5 \mathrm{DU}$ to the decrease in total column of ozone.

The aim of this paper is to examine the origin of the feature between the isentropes of 550 and $650 \mathrm{~K}$ (hereafter referred to as "the notch"), seen in the ozone profiles on 24 December and 31 December 1998 (not shown). On 24 December, the ozone mixing ratio on the $600 \mathrm{~K}$ isentrope, was $\sim 40 \%$ less than on 14 December. In the subsequent ozonesonde flight, on 31 December 1998, the notch was much smaller, spanning between the isentropes of $\sim 570$ and $\sim 590 \mathrm{~K}$.

To explain the notch, we investigated its origin by first evaluating the ozone distribution over a more global area derived from satellite measurements. The ozone data used were from the Polar Ozone and Aerosol Measurement (POAM) III instrument (Lucke et al., 1999). Since POAM is a solar occultation instrument, the measurements in each hemisphere are restricted to a single latitude each day. One of the methods for calculating ozone mixing ratios over a much wider range of geographic locations than were actually observed is by advecting the measurements forward or backward in time, thus filling in some of the gaps in data (Pierce et al., 1994; Morris et al., 1995). On the other hand, the same goal can be achieved by using well-established $\mathrm{PV} / \mathrm{O}_{3}$ mapping techniques (Butchart and Remsberg, 1986; Schoeberl et al., 1989). The mapping assumes that $P V$ is a conserved quantity during adiabatic transport and can thus be used as a tracer of atmospheric motions. Under this assumption, any dynami- cally controlled trace species in the stratosphere should exhibit a single, well-defined relationship that defines its correlation with PV anywhere on a given potential temperature surface at any given point in time (e.g. Leovy et al., 1985; Allaart et al., 1993). While the validation of such a mapping technique in a dynamically quiescent period (northern hemisphere winter of 1999-2000), using POAM III ozone measurements, was done by Randall et al. (2002), in this paper the use of that same mapping method in a dynamically active period (during the Antarctic vortex breakdown) is discussed.

Proxy ozone mixing ratios over middle and high southern latitudes in December 1998 were calculated according to the method of Randall et al. (2002). At that time the POAM measurement locations were about $20^{\circ}$ poleward of Lauder. Briefly, the POAM data from a seven-day period centered around the day of interest were used to derive daily quadratic fits of ozone and PV (where the PV values at the POAM measurement locations were determined from a bilinear interpolation of the PV field obtained from the United Kingdom Meteorological Office (UKMO) analyses (Swinbank and O'Neill, 1994). Examples of the POAM data on the potential temperature surface of $600 \mathrm{~K}$ for 7 and $24 \mathrm{De}-$ cember 1998, plotted against PV, are shown in Fig. 2, along with the quadratic fits to the data.

On 7 December, the fit matches the data reasonably well. The lowest ozone mixing ratio values correspond to the lowest PV values, and vice versa, which is consistent with the fact that on this day and on this isentropic surface, the Antarctic vortex still existed (see below). On the other hand, this is not true for the fit for 24 December. Furthermore, there is substantial scatter in the data for 24 December, which is suggestive of the presence of significant small scale structure 

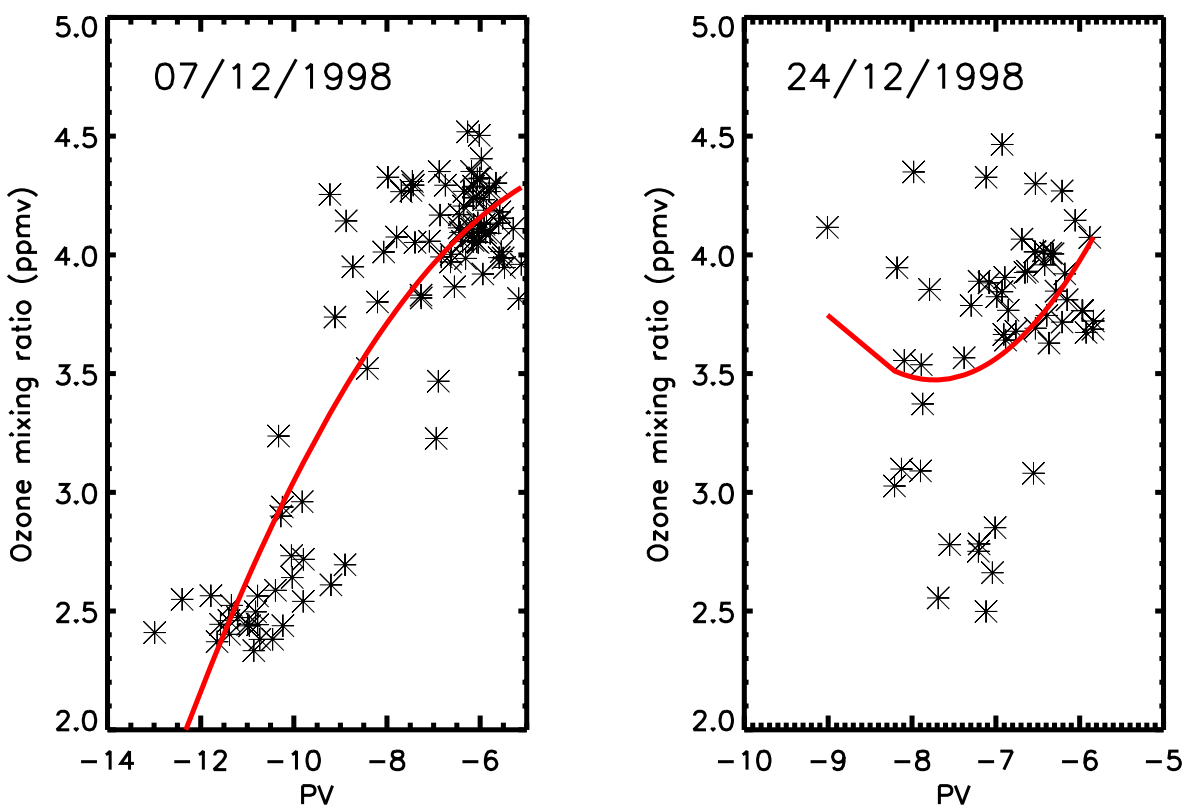

Fig. 2. Ozone mixing ratio (in ppmv) and PV (in $10^{-5} \cdot \mathrm{K} \mathrm{kg}^{-1} \mathrm{~m}^{2} \mathrm{~s}^{-1}$ ) for the Southern Hemisphere POAM III measurements on the $600 \mathrm{~K}$ isentropic surface, for two days, 7 December (left) and 24 December (right) 1998. The red line represents the quadratic fits.

in the ozone distribution; this is discussed in more detail below. Daily fits such as those depicted in Fig. 2 were used to derive proxy ozone throughout the southern middle and high latitudes. In the regions where PV values were outside the PV range of the POAM measurements, the proxy ozone values were calculated by extrapolating the $\mathrm{PV} / \mathrm{O}_{3}$ fit. An example of the PV and proxy ozone maps, for 24 December 1998 , on the $600 \mathrm{~K}$ isentrope, is given in Fig. 3.

The proxy ozone derived in such a manner was compared with Lauder ozonesonde data for 14 and 24 December 1998. The ozone values at Lauder were bilinearly interpolated from the proxy ozone field, and the results are shown in Fig. 4.

The agreement is very good, except on the $600 \mathrm{~K}$ surface on 24 December. The proxy ozone map in Fig. 3 therefore does not reproduce the low ozone values on 24 December 1998 , at $600 \mathrm{~K}$ over Lauder. The ozone mixing ratio derived from the $\mathrm{PV} / \mathrm{O}_{3}$ fit is approximately $1 \mathrm{ppmv}$ greater than what the ozonesonde measured (Fig. 4).

As mentioned above, however, the POAM ozone data, from which the 24 December proxy was determined, were only poorly represented by the quadratic $\mathrm{PV} / \mathrm{O}_{3}$ relation (Fig. 2). The double-valued nature of the $\mathrm{PV} / \mathrm{O}_{3}$ correlation (i.e. two very different values of ozone for the same value of PV) has two implications. First, small scale features in the PV field, including any possible vortex remnants, are not adequately represented, probably because the UKMO data have relatively low horizontal resolution $\left(2.5^{\circ}\right.$ in latitude, $3.75^{\circ}$ in longitude). Second, over this dynamically active period (seven days centred around 24 December), the change in the PV values associated with vortex remnants might lead to decorrelation of PV and ozone.

Furthermore, even if the resolution of the PV field can be improved and assuming that PV and ozone are correlated, the quadratic $\mathrm{PV} / \mathrm{O}_{3}$ fit may not be sufficient to define the observed structure in the $\mathrm{PV} / \mathrm{O}_{3}$ correlation on this particular day. In principle, the $\mathrm{PV} / \mathrm{O}_{3}$ fitting can incorporate numerical functions or higher-order analytic functions more accurately to represent small-scale structure in the ozone distributions. Drawbacks to this include the inability to extrapolate beyond the measured range of PV values if numerical functions are used and the introduction of spurious structure with higherorder analytic functions.

In this work, the insufficient resolution of the PV field is addressed whilst retaining the quadratic fitting procedure validated (in more quiescent conditions) by Randall et al. (2002). To improve the geographic resolution of the ozone field at the time the notch was observed, reverse domain filling (RDF) analyses (Sutton et al., 1994) were performed. Air parcels, initialized over the New Zealand region $\left(34-48^{\circ} \mathrm{S}\right.$, $162-178^{\circ} \mathrm{E}$ on a $1^{\circ}$ latitude by $1^{\circ}$ longitude grid) from $23-26$ December 1998, were traced back to their point of origin on 7 December 1998 (the choice of this date is discussed below). Isentropic trajectories at two potential temperature surfaces within the notch, 550 and $600 \mathrm{~K}$, were examined. In theory, assuming no photochemical change and negligible vertical motion and mixing, the high-resolution ozone field on 23-26 December can be computed by using the ozone distribution on 7 December and simply carrying it forward in time along the computed trajectories.

The RDF code uses winds interpolated from the original UKMO grid onto a $5^{\circ} \times 5^{\circ}$ horizontal grid and a vertical grid ranging from $2 \mathrm{~km}$ to $60 \mathrm{~km}$ in 2-km increments. A fourth order Runge-Kutta method is used to integrate advection equations; bilinear interpolation is used to calculate winds at parcel positions. The coordinate system of the code is spherical, apart from a polar cap of $25^{\circ}$ radius where it is polar- 


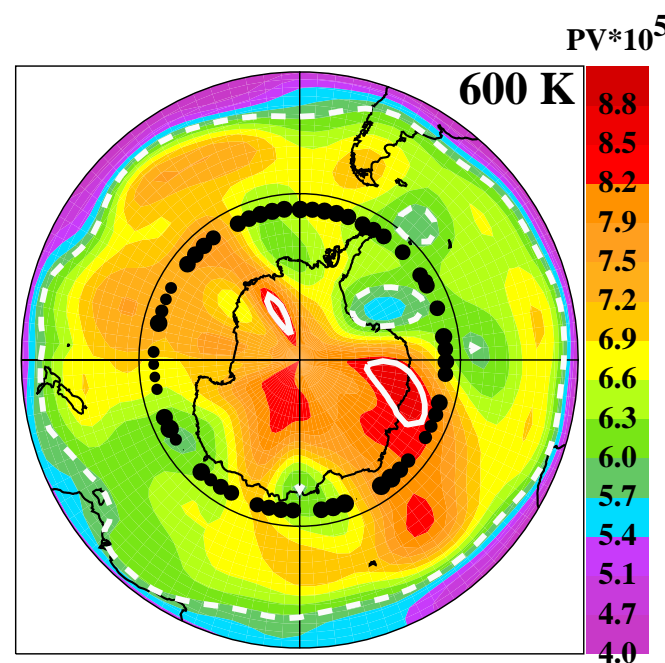

PV FIELD

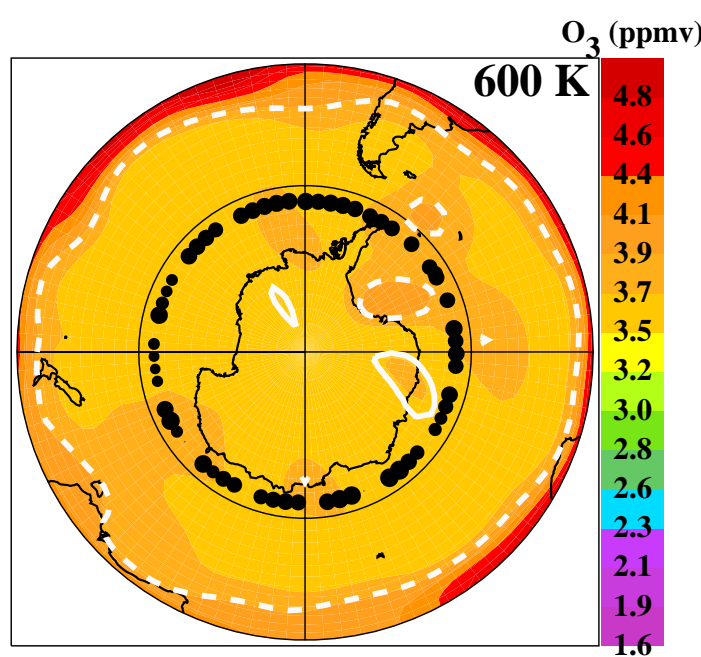

$\mathrm{PROXY} \mathrm{O}_{3}$

Fig. 3. Polar stereographic $\left(30-90^{\circ} \mathrm{S}\right)$ low-resolution absolute PV (in $\mathrm{K} \mathrm{kg}^{-1} \mathrm{~m}^{2} \mathrm{~s}^{-1}$ ) and ozone fields on the $600 \mathrm{~K}$ isentropic surface, on 24 December 1998. Dots represent the actual POAM measurement locations. The overplotted contours border the regions where the absolute PV was higher (solid) and lower (dashed) than that sampled by POAM.
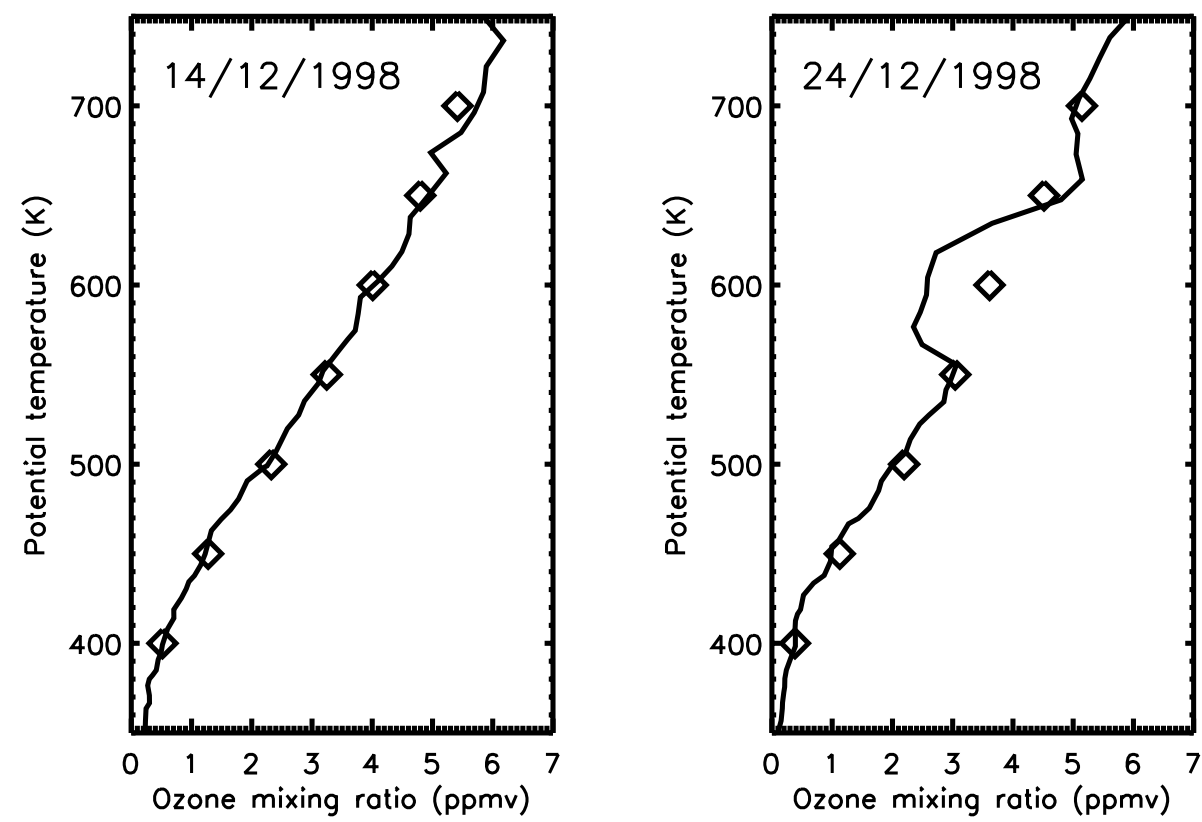

Fig. 4. Lauder ozonesonde (full line) and POAM ozone (diamonds) comparison for seven isentropic surfaces (400-700 K) on 14 and 24 December 1998 .

stereographic. The time-step for calculations was two hours.

A procedure used to determine the vortex breakdown dates was based on the work of Nash et al. (1996), where the product of the first derivative of the PV versus equivalent latitude and mean wind speed along PV isolines is representative of vortex strength. For the years 1991-2000, and the isentropes of 500,550 and $600 \mathrm{~K}$, the daily maxima of the product were calculated. For each calendar day, the median of the daily maxima during this ten-year period was then calculated, producing a reference climatology of the product maximum for the years 1991-2000. For each year, the date when the daily maximum fell below $10 \%$ of the maximum value of the reference climatology, was taken as the breakdown date. The calculated dates for the $500 \mathrm{~K}$ isentrope are in good agreement with the dates determined by Waugh and Randel (1999), and consistent with the analysis of Waugh et al. (1999).

7 December 1998 was chosen as the initial day for our analysis for two reasons. The fact that it is a few days before the determined breakdown dates for 550 and $600 \mathrm{~K}$, ensures that the analysis was done for the period when the Antarctic 

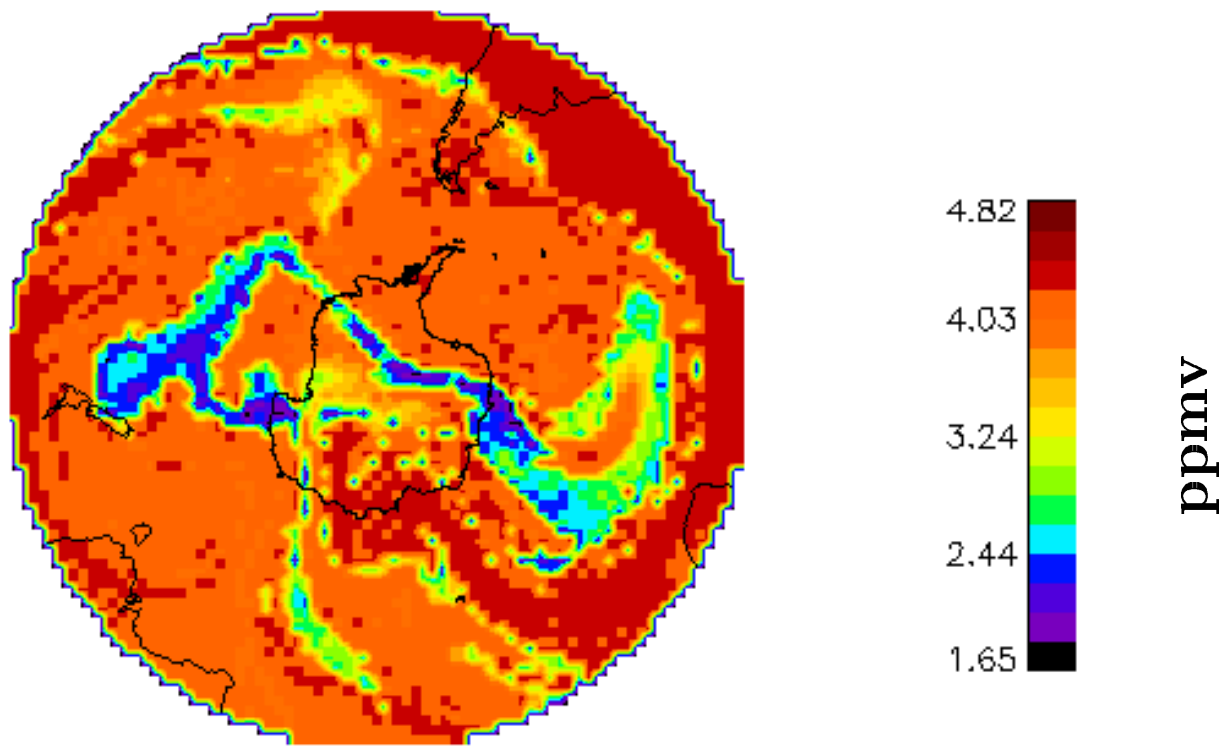

\section{December}

Fig. 5. Polar stereographic $\left(30-90^{\circ} \mathrm{S}\right)$ high-resolution ozone map on the $600 \mathrm{~K}$ surface, on 24 December 1998.

vortex was still intact and the vortex properties were well defined (e.g. PV value of the vortex edge). On the other hand, by choosing 7 December as opposed to some earlier date, the RDF trajectories were not run for longer than 19 days. Nevertheless, as a test of sensitivity to the initial date, all the calculations were additionally performed by using 5 December and 9 December as the initial days.

Parcels originating within the vortex on 7 December were identified by comparing their PV values with the PV values defining the vortex edge according to the method of Nash et al. (1996). On 23 December, on the 550 and $600 \mathrm{~K}$ surfaces, no vortex parcels were present above the New Zealand region. On 24 December, $\sim 10 \%$ and $\sim 25 \%$ of the total number of parcels over the New Zealand region on the 550 and $600 \mathrm{~K}$ potential surfaces, respectively, originated within the vortex. On 25 December there were more than $50 \%$ of the vortex parcels on both isentropes (the South Island of New Zealand was completely covered by the vortex air at $600 \mathrm{~K}$ ). On 26 December, at $550 \mathrm{~K}$, the number of vortex parcels was more than $80 \%$ and, at $600 \mathrm{~K}$, it dropped to $\sim 45 \%$. The number of parcels for all four days examined and for both of the isentropes, obtained by using 5 December and 9 December as the initial days, did not differ from the above results by more than $4 \%$.

To investigate the ozone values associated with the vortex parcels, proxy ozone values were derived according to the POAM-based quadratic $\mathrm{PV} / \mathrm{O}_{3}$ fit for 7 December. The parcels were then "labelled" with these ozone values and their locations at the start of the trajectory calculation (e.g. 24 December) were used to produce a "high-resolution" proxy ozone map for that date. In the process of calculating highresolution ozone values, "cut-off" levels were set at the min- imum and maximum PV value at the POAM measurement locations on 7 December. Hence, unlike the low-resolution case, no extrapolation of the $\mathrm{PV} / \mathrm{O}_{3}$ fit was done, thus preventing the occurrence of unrealistically high or low ozone values. The high-resolution proxy ozone map for $24 \mathrm{De}-$ cember on the $600 \mathrm{~K}$ surface is shown in Fig. 5. The same calculations performed, by going back to 5 December and 9 December, produced high-resolution maps which are qualitatively identical to the one in Fig. 5.

Figure 5 shows a filament of ozone-poor air situated above the South Island. It also reveals the fine details in the stratosphere after the Antarctic vortex broke down. None of this is evident in the low-resolution proxy ozone map (Fig. 3). It is clear that the discrepancy between the ozonesonde and low-resolution $\mathrm{PV} / \mathrm{O}_{3}$ proxy ozone values for 24 December (Fig. 4) is due to small-scale horizontal variations in the ozone field on 24 December that the $\mathrm{PV} / \mathrm{O}_{3}$ fitting technique does not accurately model.

This result illustrates the value of combining $\mathrm{PV} / \mathrm{O}_{3}$ mapping with the RDF calculations. The mapping as applied in Randall et al. (2002), gives excellent results when the PV field is relatively smooth and lacking in fine-scale horizontal structure but works less well during dynamically active times such as vortex breakdown, when the presence of filaments can lead to a much more highly structured ozone field. In conjunction with the $\mathrm{PV} / \mathrm{O}_{3}$ proxy fields calculated during less active times, the RDF calculations enable the reconstruction of ozone fields even in the presence of a highly structured PV field.

Finally, to examine whether the air contained in the notch was chemically depleted, the vertical motion of vortex air parcels between 1 October, the time around which deple- 


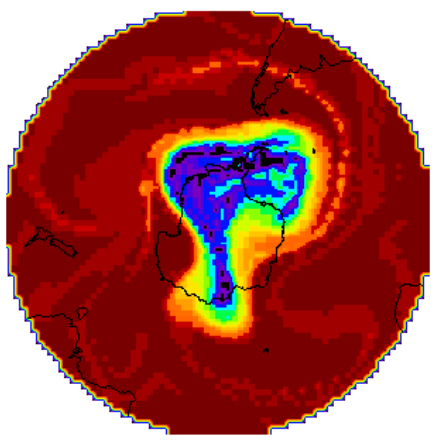

5 December

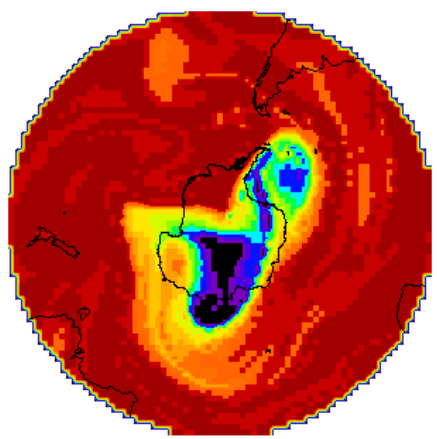

17 December

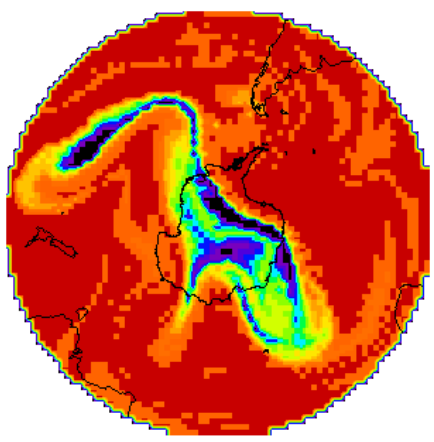

24 December

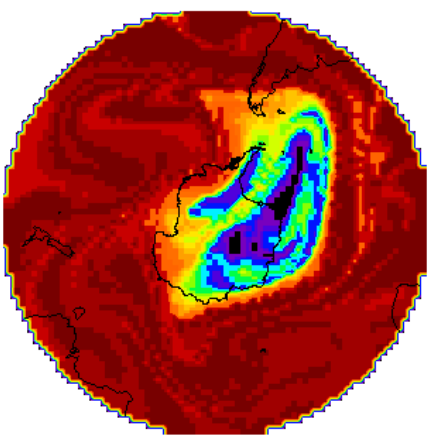

9 December

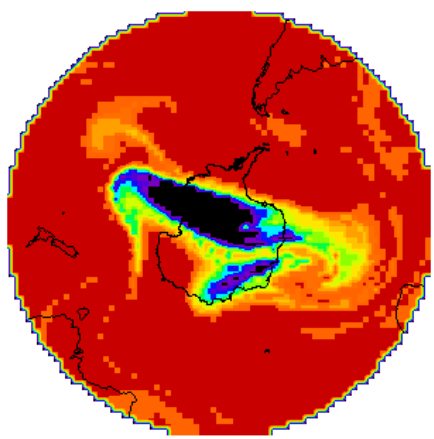

21 December

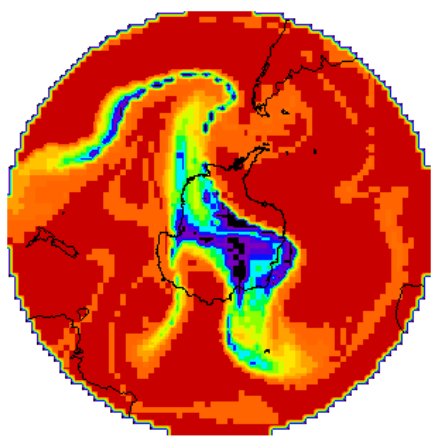

25 December

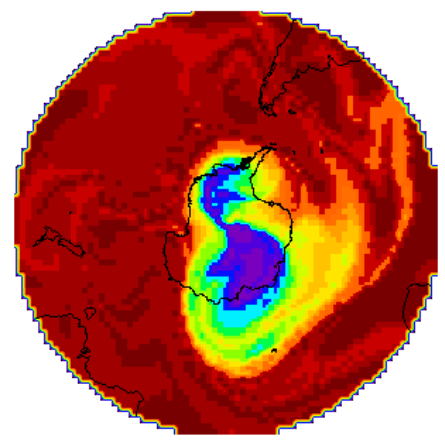

14 December

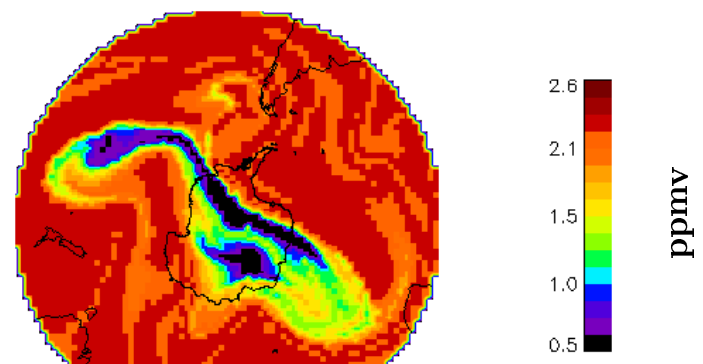

23 December

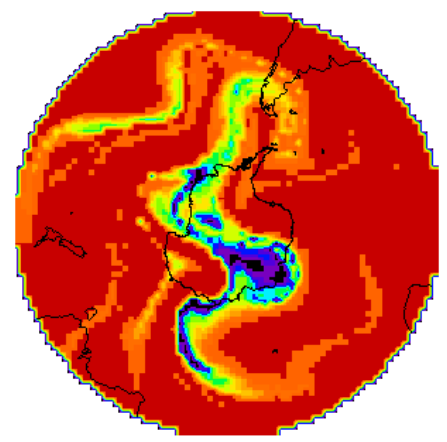

27 December

Fig. 6. Polar stereographic $\left(30-90^{\circ} \mathrm{S}\right)$ high-resolution ozone maps on the $500 \mathrm{~K}$ surface for nine selected days in December 1998.

tion reaches maximum, and 7 December 1998, was analyzed. Diabatic RDF calculations, for the parcels that were inside the Antarctic vortex on 7 December 1998, were performed with the heating rates of Rosenfield et al. (1994). The ozone profiles used in the calculations of the heating rates were monthly, zonally averaged profiles for 1979 derived from the solar backscattered ultraviolet instrument on Nimbus-7 (McPeters et al., 1984), except for the Antarctic region from 23 August to 31 October. For this time period, the daily, twodimensional (latitude-height) fields reconstructed (Schoeberl et al., 1989; Lait et al., 1990) from ozone values measured by Proffitt et al. (1989) during the 1987 Antarctic Airborne
Ozone Experiment, were used.

The results for $600 \mathrm{~K}$ showed that over the examined period, the air parcels descended from higher altitudes (mean potential temperature surface of $\sim 700 \mathrm{~K}$ ), where ozonedepleting heterogeneous chemical reactions do not take place (Collins et al., 1993). Smaller ozone mixing ratios inside the vortex, compared to the surrounding air, were caused by two dynamical effects. First, horizontal mixing of midlatitude ozone-rich air, from which the vortex air is isolated, leads to accumulation of ozone outside the vortex (Randall et al., 1995). Second, diabatic descent of vortex air above the ozone mixing ratio peak, reduces ozone levels at those 

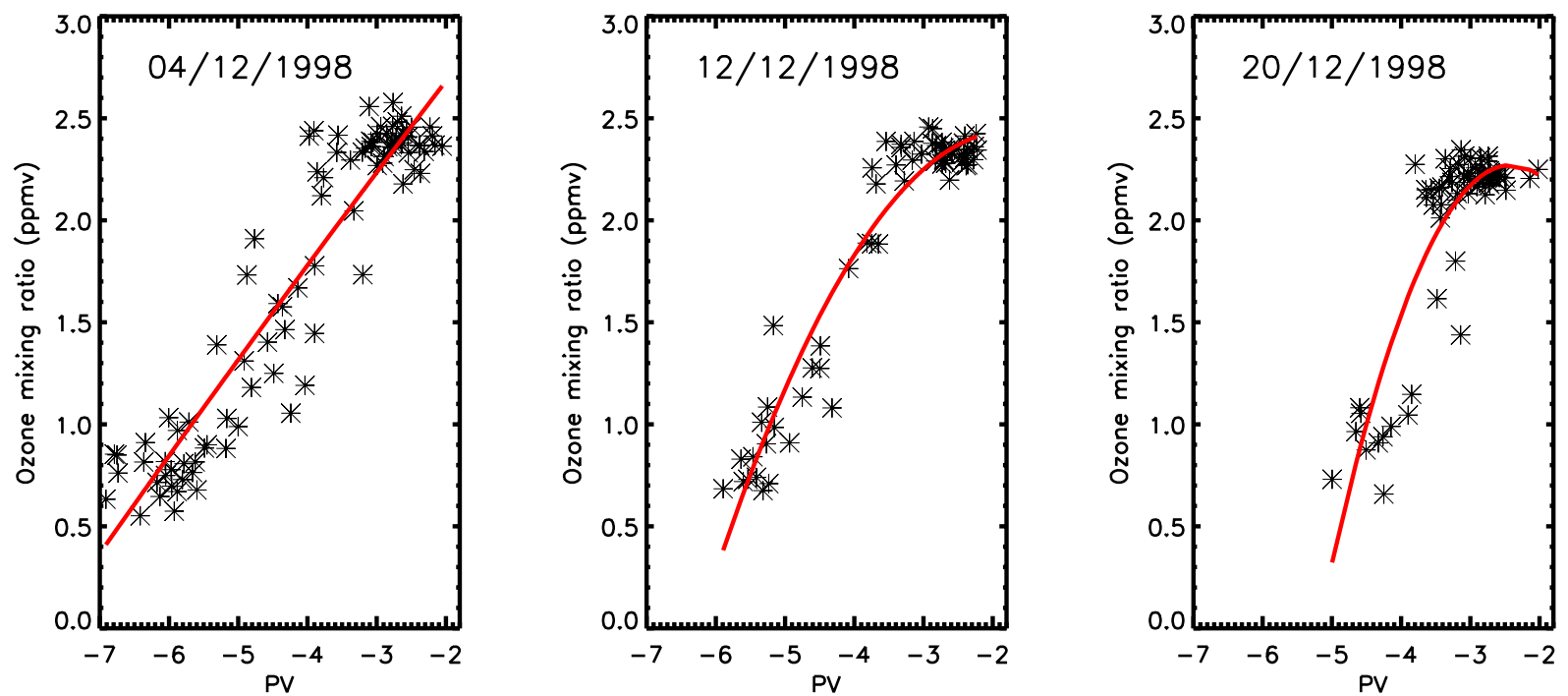

Fig. 7. Ozone mixing ratio (in ppmv) and PV (in $10^{-5} \cdot \mathrm{K} \mathrm{kg}^{-1} \mathrm{~m}^{2} \mathrm{~s}^{-1}$ ) for the Southern Hemisphere POAM III measurements on the $500 \mathrm{~K}$ isentropic surface, for three days, 4, 12 and 20 December 1998. The red line represents the quadratic fits.

altitudes (Bevilacqua et al., 1997). In contrast, the results for $550 \mathrm{~K}$ showed that a significant number of air parcels originated between 500 and $600 \mathrm{~K}$, in the region of the ozone hole, where they underwent chemical depletion.

\section{Discussion}

In this section we discuss combining the $\mathrm{PV} / \mathrm{O}_{3}$ mapping and RDF calculations to illustrate the evolution of highresolution ozone reconstructions during December. Figure 6 shows a selection of high-resolution proxy ozone maps for December 1998 on the $500 \mathrm{~K}$ potential temperature surface. Vertical motion calculations showed that the air at this isentrope mostly ascended from lower altitudes (mean potential temperature surface of $\sim 480 \mathrm{~K}$ ) where ozone depletion is most severe. Hence, the $500 \mathrm{~K}$ potential temperature surface was chosen to illustrate the evolution of the Antarctic vortex ozone-depleted air.

The calculations of the proxy ozone mixing ratios consisted of two steps. In the first step, high-resolution PV values were derived from isentropic RDF calculations run for five days back from the day of interest. The averaged heating rates for the month of December 1998 on the $500 \mathrm{~K}$ isentrope, for the region poleward of $60^{\circ} \mathrm{S}$, were approximately $-0.4 \mathrm{~K} /$ day; for midlatitudes $\left(30-60^{\circ} \mathrm{S}\right)$ were $\sim 0.3 \mathrm{~K} /$ day. Therefore, the errors in the calculations arising from the assumption of two-dimensional flow are negligible. In the second step, the quadratic $\mathrm{PV} / \mathrm{O}_{3}$ fit on the initial day was used to derive ozone at the trajectory end-points. In this manner, the advantages of both of the methods were used. Even though the RDF technique explicitly neglects mixing between parcels, the process of mixing is implicitly represented in the daily POAM measurements and thus only the last five days of mixing are neglected in the high-resolution proxy ozone maps.

The first plot (5 December) in Fig. 6 shows ozone-depleted air well confined within the vortex and relatively high ozone values in midlatitudes. The following three plots show a highly distorted vortex and filaments peeling off from the edge of the vortex and reaching midlatitudes. At the same time, the midlatitude ozone levels steadily decreased. The last five plots show the period 21-27 December, in which an evolution of one of the vortex filaments can be examined. On 21 December, during the process of vortex breakdown, the filament started forming south-east of New Zealand. Over the period of seven days it can be seen how the shape and the size of the filament changed. On 24 December, the filament is in the vicinity of New Zealand but not reaching it. RDF runs performed with different initial days, including 7 December, showed that the location of this filament did not change. In fact, this filament is a part of the same vortex remnant as the filament at $600 \mathrm{~K}$, situated above New Zealand on this day, and different positioning of these two filaments is a consequence of vertical misalignment (Waugh et al., 1997). After 24 December, the ozone amounts inside the filament increased while the width of the filament decreased. By 27 December, this filament had a noticeably smaller area with the lowest ozone values approximately three times greater than on 24 December.

Three $\mathrm{PV} / \mathrm{O}_{3}$ fits (along with the data) used to generate the high-resolution proxy ozone maps on 9, 17 and 25 December are shown in Fig. 7. From these illustrative plots, the evolution of PV and ozone values sampled by POAM as well as the evolution of the $\mathrm{PV} / \mathrm{O}_{3}$ fit, can be seen. The minimum $\mathrm{PV}$ values changed more rapidly than the sampled minimum ozone values. On the other hand, the maximum PV values were almost constant, while there was a slight decrease in the ozone values corresponding to those maximum PV val- 
ues. Hence, the high-resolution proxy ozone maps in Fig. 6 showing the decrease in midlatitude ozone values, are consistent with the POAM measurements.

The temporal evolution of the high-resolution ozone field illustrated in Fig. 6, shows that, throughout the month of December 1998, the vortex air was continually transported into midlatitudes. This suggests that the overall decrease in the midlatitude ozone mixing ratios seen at the end of December was at least partly due to the dilution of the ozone-depleted vortex air. This conclusion also offers a possible explanation for the decrease observed in the ozone mixing ratios on $500 \mathrm{~K}$, between 14 and 24 December (Fig. 1).

\section{Conclusion}

An analysis of the causes of the anomalous ozone profile on 24 December 1998 over Lauder has been performed using ozonesonde data, RDF calculations and POAM III ozone measurements. The analysis shows that in the period 2426 December, after the Antarctic vortex breakdown, a vortex remnant on the 550 and $600 \mathrm{~K}$ isentropes was situated above New Zealand. The $600 \mathrm{~K}$ vortex remnant air descended from higher altitudes and was not subjected to ozone-depleting chemical reactions while the $550 \mathrm{~K}$ air originated from the ozone hole region.

The $\mathrm{PV} / \mathrm{O}_{3}$ fitting technique combined with RDF calculations has been used to produce high-resolution proxy ozone maps. These maps, unlike low-resolution maps, show the highly structured state of the atmosphere following the vortex breakdown. They can therefore be used to investigate the outflow of ozone-poor air which occurs after the vortex breakdown and its influence on midlatitude ozone levels. Furthermore, the maps on the $500 \mathrm{~K}$ isentrope show the dilution effect, whereby the midlatitude ozone levels decrease by mixing of ozone-depleted vortex air into midlatitudes.

Acknowledgements. We are grateful for the provision of the UKMO stratospheric assimilation data (via the BADC) and for the POAM data provided by the POAM analysis team at the Naval Research Laboratory. This work had been funded in part by a NIWA doctoral scholarship held at the University of Canterbury.

Topical Editor D. Murtagh thanks two referees for their help in evaluating this paper.

\section{References}

Allaart, M. A. F., Kelder, H., and Heijboer, L. C.: On the relation between ozone and potential vorticity, Geophys. Res. Lett., 20, 811-814, 1993.

Atkinson, R. J. and Plumb, R. A.: Three-dimensional ozone transport during the ozone hole breakup in December 1987, J. Geophys. Res., 102, 1451-1466, 1997.

Atkinson, R. J., Matthews, W. A., Newman, P. A., and Plumb, R. A.: Evidence of the mid-latitude impact of Antarctic ozone depletion, Lett. Nat., 340, 290-294, 1989.

Bevilacqua, R. M., Aellig, C. P., Debrestian, D. J., Fromm, M. D., Hoppel, K., Lumpe, J. D., Shettle, E. P., Hornstein, J. S., Randall,
C. E., Rusch, D. W., and Rosenfield, J. E.: POAM II ozone observations in the Antarctic ozone hole in 1994, 1995, and 1996, J. Geophys. Res., 102, 23 643-23 657, 1997.

Bodeker, G. E., Boyd, I. S., and Matthews, W. A.: Trends and variability in vertical ozone and temperature profiles measured by ozonesondes at Lauder, New Zealand: 1986-1996, J. Geophys. Res., 103, 28 661-28 681, 1998.

Bodeker, G. E., Struthers, H. A., and Connor, B. J.: Dynamical containment of Antarctic ozone depletion, Geophys. Res. Lett., 29, doi:10.1029/2001GL014 206, 2002.

Bowman, K. P.: Large-scale isentropic mixing properties of the Antarctic polar vortex from analyzed winds, J. Geophys. Res., 98, 23 013-23 027, 1993.

Butchart, N. and Remsberg, E. E.: The area of the stratospheric polar vortex as a diagnostic for tracer transport on an isentropic surface, J. Atmos. Sci., 43, 1319-1339, 1986.

Collins, R. L., Bowman, K. P., and Gardner, C. S.: Polar stratospheric clouds at the South Pole in 1990: Lidar observations and analysis, J. Geophys. Res., 98, 1001-1010, 1993.

Eckman, R. S., Grose, W. L., Turner, R. E., and Blackshear, W. T.: Polar ozone depletion: A three-dimensional chemical modeling study of its long-term global impact, J. Geophys. Res., 101, 22 977-22 989, 1996.

Knudsen, B. M., Lahoz, W. A., O'Neill, A., and Morcrette, J.$\mathrm{J} .:$ Evidence for a substantial role for dilution in northern midlatitude ozone depletion, Geophys. Res. Lett., 25, 4501-4504, 1998.

Lait, L. R., Schoeberl, M. R., Newman, P. A., Proffitt, M. H., Loewenstein, M., Podolske, J. R., Strahan, S. E., Chan, K. R., Gary, B., Margitan, J. J., Browell, E., McCormick, M. P., and Torres, A.: Reconstruction of $\mathrm{O}_{3}$ and $\mathrm{N}_{2} \mathrm{O}$ fields from ER-2, DC-8, and balloon observations, Geophys. Res. Lett., 17, 521524, 1990.

Leovy, C. B., Sun, C.-R., Hitchman, M. H., Remsberg, E. E., Russell III, J. M., Gordley, L. L., Gille, J. C., and Lyjak, L. V.: Transport of ozone in the middle stratosphere: Evidence for planetary wave breaking, J. Atmos. Sci., 42, 230-244, 1985.

Lucke, R. L., Korwan, D. R., Bevilacqua, R. M., Hornstein, J. S., Shettle, E. P., Chen, D. T., Daehler, M., Lumpe, J. D., Fromm, M. D., Debrestian, D., Neff, B., Squire, M., König-Langlo, G., and Davies, J.: The Polar Ozone and Aerosol Measurement (POAM) III instrument and early validation results, J. Geophys. Res., 104, 18 785-18 799, 1999.

McPeters, R. D., Heath, D. F., and Bhartia, P. K.: Average ozone profiles for 1979 from the NIMBUS-7 SBUV instrument, J. Geophys. Res., 84, 5199-5214, 1984.

Morris, G. A., Schoeberl, M. R., Sparling, L. C., Newman, P. A., Lait, L. R., Elson, L., Waters, J., Suttie, R. A., Roche, A., Kumer, J., and Russell III, J. M.: Trajectory mapping and applications to data from the Upper Atmosphere Research Satellite, J. Geophys. Res., 100, 16491-16505, 1995.

Nash, E. R., Newman, P. A., Rosenfield, J. E., and Schoeberl, M. R.: An objective determination of the polar vortex using Ertel's potential vorticity, J. Geophys. Res., 101, 9471-9478, 1996.

Pierce, R. B., Grose, W. L., Russell III, J. M., and Tuck, A. F.: Evolution of southern hemisphere spring air masses observed by HALOE, Geophys. Res. Lett., 21, 213-216, 1994.

Proffitt, M. H., Steinkamp, M. J., Powell, J. A., McLaughlin, R. J., Mills, O. A., Schmeltekopf, A. L., Thompson, T. L., Tuck, A. F., Tyler, T., and Winkler, R. H.: In situ ozone measurements within the 1987 Antarctic ozone hole from a high-altitude ER-2 aircraft, J. Geophys. Res., 94, 16547-16 555, 1989. 
Randall, C. E., Rusch, D. W., Bevilacqua, R. M., Lumpe, J., Ainsworth, T. L., Debrestian, D., Fromm, M., Krigman, S. S., Horstein, J. S., Shettle, E. P., Olivero, J. J., and Clancy, R. T.: Preliminary results for POAM II: Stratospheric ozone at high northern latitudes, Geophys. Res. Lett., 22, 2733-2736, 1995.

Randall, C. E., Lumpe, J. D., Bevilacqua, R. M., Hoppel, K. W., Fromm, M. D., Salawitch, R. J., Swartz, W. H., Lloys, S. A., Kyro, E., von der Gathen, P., Claude, H., Davies, J., DeBacker, H., Dier, H., Molyneux, M. J., and Sancho, J.: Reconstruction of 3D ozone fields using POAM III during SOLVE, J. Geophys. Res., 107, doi:10.1029/2001JD000 471, 2002.

Rosenfield, J. E., Newman, P. A., and Schoeberl, M. R.: Computations of diabatic descent in the stratospheric polar vortex, J. Geophys. Res., 99, 16677-16689, 1994.

Schoeberl, M. R., Lait, L. R., Newman, P. A., Martin, R. L., Proffitt, M. H., Hartmann, D. L., Loewenstein, M., Podolske, J., Strahan, S. E., Anderson, J., Chan, K. R., and Gary, B.: Reconstruction of the constiuent distribution and trends in the Antarctic polar vortex from ER-2 flight observations, J. Geophys. Res., 94, 16815$16845,1989$.

Sutton, R. T., Maclean, H., Swinbank, R., O’Neill, A., and Taylor,
F. W.: High-resolution stratospheric tracer fields estimated from satellite observations using Lagrangian trajectory calculations, J. Atmos. Sci., 51, 2995-3005, 1994.

Swinbank, R. and O'Neill, A.: A stratosphere-troposphere data assimilation system, Mon. Wea. Rev., 122, 686-702, 1994.

Waugh, D. W. and Randel, W. J.: Climatology of Arctic and Antarctic polar vortices using elliptical diagnostics, J. Atmos. Sci., 56, 1594-1613, 1999.

Waugh, D. W., Plumb, R. A., Elkins, J. W., Fahey, D. W., Boering, K. A., Dutton, G. S., Volk, C. M., Keim, E., Gao, R.-S., Daube, B. C., Wofsey, S. C., Loewenstein, M., Podolske, J. R., Chan, K. R., Proffitt, M. H., Kelly, K. K., Newman, P. A., and Lait, L. R.: Mixing of polar vortex air into middle latitudes as revealed by tracer-tracer scatterplots, J. Geophys. Res., 102, 13 119-13 134, 1997.

Waugh, D. W., Randel, W. J., Pawson, S., Newman, P. A., and Nash, E. R.: Persistence of the lower stratospheric polar vortices, J. Geophys. Res., 104, 27 191-27 201, 1999.

WMO, Scientific Assessment of Ozone Depletion: 1998, Global Ozone Research and Monitoring Project, Tech. Rep. 44, World Meteorological Organization, 1999. 